\title{
MRS Elects New Officers, Councillors for 1995
}

Ballot results are final for the MRS yearly election that just ended October 14, 1994: MRS members elected three officers and six councillors to join 1995 MRS President Julia M. Phillips of AT\&T Bell Laboratories.

\section{MRS Officers}

\section{President}

Julia M. Phillips (1995)

AT\&T Bell Laboratories

Immediate Past President

John C. Bravman (1995)

Stanford University

First Vice President (President Elect)

*Carl V. Thompson (1995)

Massachusetts Institute of Technology

Second Vice President

*Robert Hull (1995)

University of Virginia

\section{Secretary}

Carl C. Koch (1995)

North Carolina State University
Treasurer

*A. Kay Hays (1996)

Sandia National Laboratories

\section{MRS Councillors}

Bill R. Appleton (1995)

Oak Ridge National Laboratory

Howard K. Birnbaum (1996)

University of Illinois-Urbana

Clifton W. Draper (1995)

AT\&T Bell Laboratories

*Charles B. Duke (1997)

Xerox Webster Research Center

Merton C. Flemings (1995)

Massachusetts Institute of Technology

*Ron Gibala (1997)

University of Michigan

J. Murray Gibson (1995)

University of Illinois-Urbana

*James M.E. Harper (1997)

IBM T.J. Watson Research Center
Kevin S. Jones (1996)

University of Florida

*Gabrielle G. Long (1997)

National Institute of Standards and Technology

Merrilea J. Mayo (1996)

Pennsylvania State University

June D. Passaretti (1995)

Minerals Technologies

*Manfred Rühle (1997)

Max-Planck-Institut für Metallforschung

Richard W. Siegel (1995)

Argonne National Laboratory

*Alan I. Taub (1997)

Ford Research Laboratory

(Terms of office expire at the end of the years indicated in parentheses.)

*Newly Elected

\section{FROM IÅ TO 60,000Å FILM MEASUREMENT SOLUTIONS BEGIN WITH RUDOLPH}

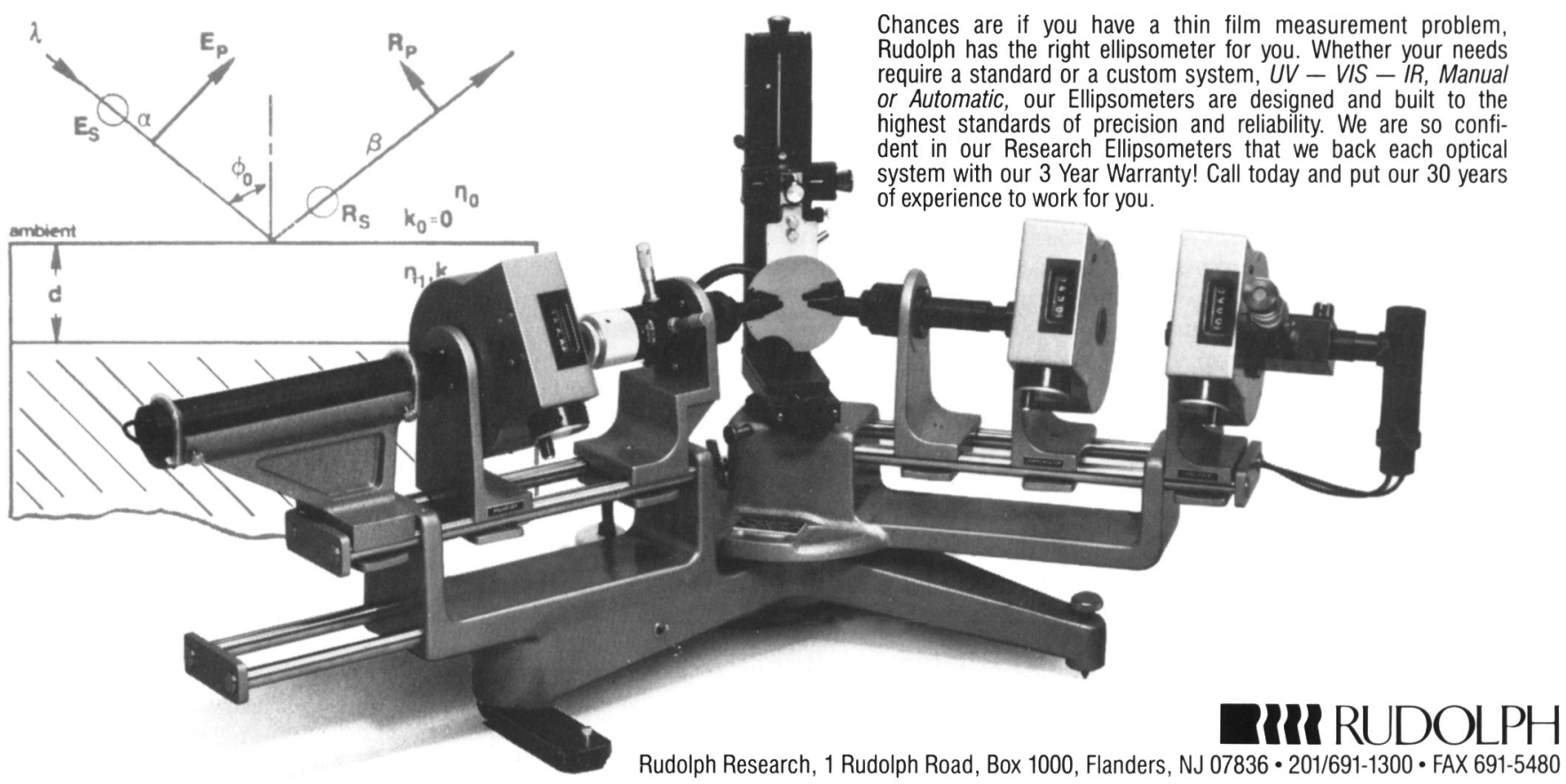

